\title{
Tipologi Hukum di Indonesia (Melihat Penggunaan Hukum Prosedural Pada Sistem Peradilan Pidana)
}

\author{
S. Sahabuddin ${ }^{1}$ \\ Fakultas Hukum, Universitas Batanghari, Jalan Slamet Riyadi Broni, Kota Jambi \\ (0741) 65351
}

\begin{abstract}
Abstrak
Tipologi hukum otonom yang masih sangat kental terasa dalam tatanan kehidupan hukum di Indonesia ditonjolkan pada kegiatan-kegiatan hukum yang dilakukan oleh organisasi / pranata hukum dengan menampakkan wajah legitimate. Memperhatikan pola-pola penegakan hukum yang dilakukan oleh pranata hukum sistem peradilan pidana di Indonesia, tergambar penerapan salah satu tipologi hukum gradasi menengah, yaitu pola-pola penegakan hukum prosedural yang memang menjadi ciri khas dan kekuatan hukum otonom (autonomous law). Penting untuk diketahui bagaimana tipologi hukum otonom ini dalam karakteristiknya serta bagaimana hukum otonom ini memberikan implikasi terhadap pranata hukum sistem peradilan pidana di Indonesia dalam etos dan gaya kerjanya.
\end{abstract}

Kata Kunci: Tipologi, hukum, otonom

\begin{abstract}
Autonomous legal typology which is still very lumpy tasted in order of life laws in Indonesia highlighted on legal activities conducted by the Organization/institution of the law by revealing the face of the legitimate. Pay close attention to the patterns of law enforcement carried out by the institution of law criminal justice system in Indonesia, reflected the application of one law of the intermediate gradations, typology, namely patterns of law enforcement procedural indeed characterizes and autonomous legal power (autonomous law). It is important to note how this autonomous legal typology in its characteristics and how it gives the autonomous law implications against the institution of law criminal justice system in Indonesia in ethos and style of work.
\end{abstract}

Keywords: Typology, legal, autonomous

\section{PENDAHULUAN}

Sejalan dengan perkembangan hukum modern, sejak awal telah memberikan bentuk atau jenis hukum di dunia, mulai dari hukum dalam bentuknya yang represif kemudian berkembang menjadi bentuk hukum yang otonom dan selanjutnya muncul hukum yang responsif serta pada saat ini kita kenal pula hukum progresif.

Hukum represif (represive law) menekankan pada model-model kekerasan dengan tujuan ketertiban dengan memberikan keluasan kekuasaan (diskresi) yang berlebihan kepada penegak hukum, namun memiliki kelemahan dalam penegakannya. Pada tahapan selanjutnya terdapat Hukum Otonom (autonomous law) menekankan pada model keadilan yang prosedural dengan memberikan legitimasi kuat kepada lembaga-lembaga penegakan hukum, namun penegakan hukum itu terbentur dengan proses-proses baku yang telah ditetapkan. Kemudian

\footnotetext{
${ }^{1}$ Dosen Fakultas Hukum Universitas Batanghari
} 
terdapat pula Hukum Responsif (responsive law) memberikan model kompetensi dengan keadilan substantif yang berorientasi pada tujuan-tujuan penegakan hukum yang bermoral serta membuka kesempatan bagi aspirasi hukum dan politik untuk berintegrasi.

Mengenai tipologi hukum otonom yang masih sangat kental terasa dalam tatanan kehidupan hukum di Indonesia ditonjolkan pada kegiatan-kegiatan hukum yang dilakukan oleh organisasi / pranata hukum dengan menampakkan wajah legitimate. Katakan saja dalam lapangan hukum pidana, kita mengenal sub-sub sistem peradilan pidana (Kepolisian, Kejaksaan, Pengadilan dan Lembaga Pemasyarakat serta Advokat) yang mengedepankan keadilan prosedural sebagai persyaratan baku kinerjanya.

Pranata-pranata hukum yang legetimate tersebut kerap kali menampakkan wajah hukum dengan tipologi yang otonom dalam pelaksanaan wewenangnya masing-masing. Untuk itu dalam tulisan ini saya mencoba mengetengahkan salah satu tipologi hukum yang dikemukakan oleh Philippe Nonet dan Philip Selznick dalam bukunya Law and Society in Transition: Toward Responsive 1978 yang diterbitkan oleh Harper and Row Publishers, New York. Yang membicarakan hukum otonom dan saya kaitkan dengan implikasinya dalam penegakan hukum di Indonesia, khususnya dalam lapangan hukum pidana.

\section{Permasalahan}

Memperhatikan pola-pola penegakan hukum yang dilakukan oleh pranata hukum sistem peradilan pidana di Indonesia, tergambar penerapan salah satu tipologi hukum gradasi menengah, yaitu pola-pola penegakan hukum prosedural yang memang menjadi ciri khas dan kekuatan hukum otonom (autonomous law). Dengan gambaran seperti itu, penulis ingin melihat bagaimana tipologi hukum otonom ini dalam karakteristiknya serta bagaimana hukum otonom ini memberikan implikasi terhadap pranata hukum sistem peradilan pidana di Indonesia dalam etos dan gaya kerjanya.

\section{METODE PENELITIAN}

Penelitian hukum normatif (normative law research) menggunakan studi kasus normatif berupa produk perilaku hukum, misalnya mengkaji undangundang. Pokok kajiannya adalah hukum yang dikonsepkan sebagai norma atau kaidah yang belaku dalam masyarakat dan menjadi acuan perilaku setiap orang. Sehingga penelitian hukum normatif berfokus pada inventarisasi hukum positif, asas-asas dan doktrin hukum, penemuan hukum dalam perkara in concreto, sistematik hukum, taraf sinkronisasi, perbandingan hukum dan sejarah hukum ${ }^{2}$

Berdasarkan penjelasan di atas, penulis memutuskan menggunakan metode penelitian hukum normatif untuk meneliti dan menulis pembahasan skripsi ini sebagai metode penelitian hukum. Penggunaan metode penelitian normatif dalam upaya penelitian dan penulisan skripsi ini dilatari kesesuaian teori dengan metode penelitian yang dibutuhkan penulis

\section{HASIL DAN PEMBAHASAN \\ Karakteristik Hukum Otonom}

\footnotetext{
${ }^{2}$ Abdulkadir Muhammad, Hukum dan Penelitian Hukum. Bandung: PT. Citra Aditya Bakti. 2004, hlm. 52
} 
Sebelum penulis membahas lebih jauh tentang pola penegakan hukum yang dilakukan oleh pranata hukum sistem peradilan pidana di Indonesia, ada baiknya penulis kemukakan dahulu beberapa pandangan Philippe Nonet dan Philip Selznick tentang hukum otonom tersebut.

Dalam buku Law and Society in Transition: Toward Responsive Law, Philippe Nonet dan Philip Selznick ${ }^{\mathbf{3}}$ telah memberikan gambaran tentang hukum otonom sebagai tipologi hukum yang mengutamakan prosedur formal baku yang dilaksanakan oleh pranata-pranata hukum yang telah memperoleh legitimasi kuat dari negara dalam suatu pengaturan hukum yang positif.

Dengan demikian, dapat dikatakan hukum otonom telah memberikan legitimasi kuat kepada lembaga-lembaga penegakan hukum untuk menjalankan hukum berdasarkan aturan-aturan yang tersedia dengan format prosedural yang telah ditetapkan.

Secara historical wacana pembicaraan mengetengahkan hukum yang otonom ini muncul sebagai akibat dari ketidakmampuan hukum represif dalam menanggulangi persoalan-persoalan hukum di tengah masyarakat, apalagi hukum represif lebih mengedepankan politik sebagai alat untuk melegetimasi kepentingan-kepentingan, sementara produk hukum yang dihasilkan masih terlihat mentah (dipaksakan) oleh lembaga politik. Hal ini tentunya akan memberikan watak otoriter yang kuat kepada kekuasaan tanpa adanya akuntabilitas.

Dari proses keinginan untuk menjinakkan hukum represif tersebut, muncul pemikiran tentang rule of law ${ }^{4}$ yang merujuk pada aspirasi hukum dan politik dalam rangka menciptakan pemerintahan berdasarkan hukum, bukan berdasarkan orang. Untuk itu diperlukan institusi-institusi yang mendapatkan otoritas / legitimasi yang cukup independen untuk memaksakan standar pengendalian dalam pelaksanaan kekuasaan pemerintahan.

Rule of Law akan lebih baik dipahami sebagai sebuah sistem kelembagaan tersendiri daripada sebuah cita-cita abstrak dengan karakteristik terciptanya lembaga-lembaga hukum yang terspesialisasi (khusus) dan relatif otonom yang kemudian mengklaim diri sebagai supremasi yang memenuhi syarat dalam bidang-bidang kompetensi yang telah ditentukan. Pandangan seperti inilah yang kemudian melahirkan rezim hukum otonom.

Ada beberapa ciri khas hukum otonom yang disampaikan oleh Philippe Nonet dan Philip Selznick ${ }^{5}$, yaitu:

1. Law is separated from politics. Characteristically the system proclaims the independence of the judiciary and draws a sharp line between legislative and judicial functions. (hukum terpisah dari politik, secara khas sistem hukum ini menyatakan kemandirian kekuasaan peradilan dan membuat garis tegas antara fungsi legislatif dan yudikatif);

${ }^{3}$ Lihat Tabel perbandingan antara hukum represif, hukum otonom dan hukum responsive, Philippe Nonet and Philip Selznick, Law and Society in Transition: Toward Responsive Law, Harper and Row Publishers, New York, 1978, halaman 16.

${ }^{4}$ Rule of Law menurut Gerald Turkel mengandung makna bahwa hukum merupakan sumber tertinggi untuk pengendali social (the law is the untimate source of social control). Dengan hal ini masyarakat meyakini bahwa hubungan-hubungan diantara mereka dibatasi oleh ketentuanketentuan hukum dan peran lembaga hukum. Lihat FX. Adji Samekto dalam editorial Satya Arinanto dan Ninuk Triyanti, Memahami Hukum Dari Konstruksi sampai Implementasi, Rajawali Pers, Jakarta, 2009, halaman 70.

${ }^{5}$ Philippe Nonet and Philip Selznick, Op.Cit. halaman 54. 
2. The legal order espouses the "model of rules". A focus on rules helps enforce a measure of official accountability; at the same time, it limits both the creativity of legal institutions and the risk of their intrusion into the political domain. (Tertib hukum mendukung "model peraturan" Fokus pada peraturan membantu menerapkan ukuran bagi akuntabilitas para pejabat; pada waktu yang sama, ia membatasi kreativitas institusi hukum maupun resiko campur tangan lembaga-lembaga hukum itu dalam wilayah politik);

3. "Procedure is the heart of law". Regularity and fairness, not substantive justice, are the first ends and the main competence of the legal order. ("prosedur adalah jantung hukum", keteraturan dan keadilan (fairness), dan bukannya keadilan substantif, merupakan tujuan dan kompetensi utama dari tertib hukum);

4. Fidelity in law is understodd as strict obedience to the rules of positive law. Criticism of existing laws must be channeled through the political process. ("ketaatan pada hukum" dipahami sebagai kepatuhan yang sempurna terhadap peraturan-peraturan hukum positif. Kritik terhadap hukum yang berlaku harus disalurkan melalui proses politik).

Berdasarkan karakteristik tersebut, jelas hukum otonom menghendaki adanya pemisahan kekuasaan antara hukum dan politik, karena dengan demikian hukum dapat bekerja independen tanpa adanya campur tangan politik. Pemisahan antara hukum dan politik merupakan strategi utama legitimasi, dengan harapan penempatan politik di bawah hukum. Elit politik dapat saja membuat putusanputusan dan mengarahkan sumber daya yang ada, namun bukan serta merta kebijakan itu menjadi legitimate secara hukum, karena ia memerlukan penilaian yang dilakukan secara terpisah.

Selanjutnya hukum otonom menempatkan "prosedur sebagai jantung dari hukum (Procedure is the heart of law)" menempati kedudukan penting dalam kinerja rezim hukum ini. Prosedur merupakan jaminan paling nyata dari suatu penerapan peraturan secara adil. Kekuasaan yang tadinya berpotensi represif dapat dikendalikan oleh due process law. Penempatan keadilan prosedural selalu ditawarkan dalam penyelesaian konflik sosial.

Kedekatan antara hukum dengan prosedur berakar pada apa yang kita sebut tawar-menawar historis hukum otonom (historic bergain of autonomous law), yang mana pengedilan setuju untuk menyerahkan kepada pihak lain masalah kebijakan substantif, sebagai gantinya pengadilan diberikan kekuasaan untuk menentukan prosesnya sendiri, yaitu mengatur syarat-syarat untuk mendapatkan akses kearah dan cara berpartisipasi dalam proses hukum. Dengan kekuasan ini, pengadilan dapat mengajukan tuntutan bahwa siapapun yang menggugat otoritas hukum harus melakukannya dengan cara yang taat asas dengan keteraturan hukum, bahkan juga terhadap pemerintah yang dalam kapasitasnya sebagai aktor hukum, diharapkan bergerak melalui saluran-saluran yang telah digariskan.

Dalam hal formalisme hukum dan peraturan, hukum otonom memfokuskan diri pada hakim dan terikat kuat pada peraturan, hakimlah yang menjadi simbol tatanan hukum, bukan polisi atau lagislator. Elaborasi ini memberikan etos dan gaya yang berbeda terhadap hukum.

Sifat ini memberikan pandangan dasar yang sangat praktis, antara lain:

a. Peraturan merupakan sebuah sumber yang handal untuk melegitimasi kekuasaan; 
b. Ketika hakim dibatasi oleh aturan perundang-undangan, maka diskresinya menjadi sempit, akibatnya yudikatif lebih mudah untuk memberikan justifikasi;

c. Kuantitas peraturan meningkat dan kompleksitas dan memberikan persoalan konsistensi, dengan demikian hakim mengandalkan interpretasi terhadap peraturan-peraturan. Praktisi-praktisi hukum otonom menjadi pembuat dan penyebar "alasan artifisial".

d. Orientasi pada peraturan cenderung membatasi tanggung jawab sistem hukum. Persyaratan harus ada peraturan hukum positif tertentu telah membantu sistem tersebut untuk menghindari tuntutan-tuntutan yang mungkin tidak mampu ia penuhi.

e. Hukum otonom tetap berkomitmen sebagai kontrol sosial, terutama dalam jangka pendek, sehingga ia menjadi garda terdepan dalam melaksanakan pengawasan dan kontrol sosial, meskipun kita tau bahwa hukum otonom telah menetralisir hukum represif.

Penempatan diri untuk taat terhadap hukum menjadi klaim tersendiri dari hukum otonom, baik pemerintahan maupun masyarakat harus menerapkan rule of law yang berbasiskan hukum dan ketertiban (law and order) yang mewajibkan masyarakat untuk taat tanpa syarat pada peraturan-peraturan yang telah diperintahkan oleh negara. Apakah peraturan itu sejalan atau bertentangan dengan rasa keadilan warga negara hal ini tidak penting, warga negara tidak menilai hukum tetapi mematuhinya.

Tidak ada penilaian-penilaian terhadap hukum dari warga negara, meskipun nantinya peraturan itu dilakukan perubahan melalui proses politik, namun warga negara harus tetap taat pada peraturan yang baru tersebut. Jadi semangat yang ingin dimunculkan oleh hukum otonom adalah ketidakleluasaan warga negara untuk berargumentasi terhadap peraturan.

Klaim ini memberikan kenyamanan pada hukum otonom untuk bergerak dan berpusat pada peraturan-peraturan (rule centered). Peraturan-peraturan yang tepat dan kewajiban-kewajiban yang tegas berjalan bergandengan. Untuk warga negara serta pejabat-pejabat publik tempat bagi diskresi dipersempit.

\section{Implikasi Hukum Otonom di Indonesia}

Indonesia sebagai negara hukum (rechtstaats) yang tetap memberikan kekuasaan / otoritas kepada lembaga-lembaga penegakan hukum (law enforcement) untuk melaksanakan wewenangnya melalui prosedural hukum yang telah ditetapkan. Hal ini tergambar dari pembukaan UUD 1945 yang menegaskan bahwa "Indonesia adalah negara kesatuan yang berlandaskan hukum (rechtstaats) dan bukan kekuasaan belaka". Jadi meskipun hukum mendapatkan otoritasnya, namun hukum diberikan kepada pemegang kekuasaannya untuk dijalankan. Dengan demikian kita dapat mengatakan Di Indonesia kekuasaan dijalankan dengan berpedoman pada peraturan perundang-undangan positif.

Kondisi seperti ini sebenarnya sinergis dengan hukum otonom yang digambarkan karakteristiknya oleh Philippe Nonet dan Philip Selznick. Otoritas itu disandarkan pada lembaga-lembaga kekuasaan yang telah diatur dalam perundang-undangannya masing-masing.

Dalam law enforcement di lapangan hukum kepidanaan yang bersifat umum (general law enforcement), terdapat beberapa institusi yang memiliki kewenangan, yaitu Kepolisian, Kejaksaan, Pengadilan, Lembaga Pemasyarakatan dan Advokat. Dalam bidang khusus Indonesia juga memiliki lembaga khusus 
yang menangani perkara-perkara khusus (special law enforcement), seperti Komisi Pemberantasan Korupsi yang memiliki kewenangan khusus dalam melakukan pemberantasan tindak pidana korupsi, Komisi Yudisial yang diberikan tugas khusus memantau kinerja dan perilaku hakim, Komisi Kepolisian, Komisi Kejaksaan (dua yang terakhir ini menjalankan fungsi pengawasan internal).

Tumbuh suburnya institusi hukum ini lebih disebabkan keinginan untuk mengawal keadilan, ketertiban dan kepastian hukum yang dalam etos kerjanya sangat mengandalkan keadilan prosedural sebagaimana yang telah dipositifkan dalam aturan perundang-undangan. Ini semua jelas ciri khas atau karakteristik dari hukum yang bertipologi otonom.

Dalam kaitan dengan persoalan ini, penulis membatasi penulisan pada 3 lembaga besar yang menjadi garda terdepan dalam mengawal keadilan dan penegakan hukum secara umum, yaitu Kepolisian, Kejaksaan dan Pengadilan. Bagaimana ketiga lembaga ini sangat menerapkan model hukum yang otonom dalam etos dan gaya, nilai ketaatan terhadap aturan hukum positif, pertahanan kelembagaan yang diperkuat tanpa memperhatikan nilai-nilai keadilan substantif.

\section{Lembaga Kepolisian}

Sejak berdirinya lembaga ini sejalan dengan kemerdekaan Republik Indonesia telah mengalami beberapa kali perubahan perundang-undangan yang mengatur otoritas institusi (Organic law), sampai yang terakhir kali (UU No.2 Tahun 2002) tetap mempertahankan pola-pola prosedural dalam pelaksanaan wewenangnya.

Lembaga Kepolisian memiliki tiga fungsi utama, yaitu fungsi pengayoman (perlindungan), fungsi pelayanan dan fungsi penegakan hukum. Dalam hal pelaksanaan fungsi penegakan hukum, lembaga ini sangat terikat dengan prosedural yang telah ditetapkan, baik dalam perundang-undangan organiknya maupun dalam hukum acara pidana yang berlaku umum serta keterikatan yang kuat pula dengan kebijakan-kebijakan yang ditetapkan oleh pimpinan institusi (Keputusan atau pedoman atau surat perintah Kapolri).

Lembaga ini juga telah menjadi la bouche de la loi (terompet perundangundangan) yang mengedepankan legalistik positivistis yang memarginalkan realitas dan moralitas penegakan hukum di Indonesia. Berikut penulis tampilkan beberapa aturan dalam UU No. 2 Tahun 2002 Tentang Kepolisian Republik Indonesia yang menggambarkan pada pola prosedural, antara lain:

Pasal 14 ayat (1) huruf g Undang-unang Nomor 2 Tahun 2002 yang mengatakan:

Dalam melakukan tugas pokok sebagaimana dimaksud dalam Pasal 13, Kepolisian Negara Republik Indonesia bertugas: (g) melakukan penyelidikan dan penyidikan terhadap semua tindak pidana sesuai dengan hukum acara pidana dan peraturan perundang-undangan lainnya

Kemudian Pasal 16 ayat (1) UU NO.2 Tahun 2002 menegaskan beberapa kewenangan kepolisian di bidang proses pidana sebagai penjabaran dari tugas polisi sebagai penegak hukum. Pasal tersebut menyatakan sebagai berikut:

Dalam rangka menyelenggarakan tugas sebagaimana dimaksud dalam Pasal 13 dan 14 di bidang proses pidana, Kepolisian Negara Republik Indonesia berwenang: 
a. melakukan penangkapan, penahanan, penggeledahan dan penyitaan;

b. melarang setiap orang meninggalkan atau memasuki tempat kejadian perkara untuk kepentingan penyidikan;

c. membawa dan menghadapkan orang kepada penyidik dalam rangka penyidikan;

d. menyuruh berhenti orang yang dicurigai dan menanyakan serta memeriksa tanda pengenal diri;

e. melakukan pemeriksaan dan penyitaan surat;

f. memanggil orang untuk didengar dan diperiksa sebagai tersangka atau saksi;

g. mendatangkan orang ahli yang diperlukan dalam hubungannya dengan pemeriksaan perkara;

h. mengadakan penghentian penyidikan;

i. menyerahkan berkas perkara kepada penuntut umum;

j. mengajukan permintaan secara langsung kepada pejabat imigrasi yang berwenang ditempat pemeriksaan imigrasi dalam keadaan mendesak atau mendadak untuk mencegah atau menangkal oarang yang disangka melakukan tindak pidana;

k. memberikan petunjuk dan bantuan penyidikan kepada penyidik pegawai negeri sipil serta menerima hasil penyidikan penyidik pegawai negeri sipil untuk diserahkan kepada penuntut umum; dan

1. mengadakan tindakan lain menurut hukum yang bertanggung jawab.

Selanjutnya dalam Kitab Undang-Undang Hukum Acara Pidana juga telah ditentukan dengan tegas tugas-tugas kepolisian selaku penegak hukum (penyelidik atau penyidik) dalam mengungkap suatu kejahatan, ketentuan itu antara lain disebutkan dalam pasal 7 ayat (1) KUHAP yang menyatakan:

a. Menerima laporan atau pengaduan dari seorang tentang adanya tindak pidana;

b. Melakukan tindakan pertama pada saat ditempat kejadian;

c. Menyuruh berhenti seorang tersangka dan memeriksa tanda pengenal diri tersangka;

d. Melakukan penangkapan, penahanan, penggeledahan dan penyitaan;

e. Melakukan pemeriksaan dan penyitaan surat;

f. Mengambil sidik jari dan memotret seorang;

g. Memanggil untuk didengar dan diperiksa sebagai tersangka atau saksi;

h. Mendatangkan orang ahli yang diperlukan dalam hubungannya dengan pemeriksaan perkara;

i. Mengadakan penghentian penyidikan;

j. Mengadakan tindakan lain menurut hukum yang bertanggung jawab.

Memperhatikan aturan-aturan yang mengikat kuat institusi kepolisian dalam penegakan hukum tersebut, jelas menunjukkan bagaimana pola prosedural yang harus ditaati oleh setiap anggota kepolisian.

Pemusatan perhatian yang ditonjolkan kepolisian terhadap aturan ini jelas akan memberikan dampak negatif dalam keluwesan (fleksibelitas) institusi dalam menghadapi social problems. Karena sangat mengandalkan peraturan dan prosedural dalam kontrol sosial.

Oliver W. Holmes" ${ }^{\mathbf{6}}$ menegaskan "Hukum tidak dapat ditemukan hanya dengan melakukan penyelidikan terhadap aturan-aturan hukum. Pemusatan

\footnotetext{
${ }^{6}$ Dalam Ahmad Ali, Op. Cit.
} 
perhatian hanya pada aturan itu justru akan membahayakan profesi hukum, karena pemusatan seperti itu akan mengarah kepada pengabaian terhadap konteks yang lebih luas yang telah memberikan makna sosial bagi hukum".

Pemusatan perhatian yang dimaksudkan oleh Holmes di atas adalah terlalu mengedepankan pola-pola legalistik yang positivistis, akibatnya model-model egosentris organik dimunculkan dalam setiap kegiatan kepolisian. Kita dapat melihat hal tersebut dalam kasus "Cicak lawan Buaya". Ketika kebenaran mulai terkuak, organisasi ini cepat-cepat melakukan manuver penyelematan organisasi dengan cara mengorbankan salah asatu atau beberapa orang anggotanya.

Model Prosedural yang paling terlihat dalam institusi kepolisian ini adalah ketika mereka melakukan wewenang penyidikan suatu kejahatan. Contohnya dalam hal kewenangan melakukan penyidikan hanya dapat dilakukan oleh penyidik yang telah ditugaskan untuk itu. Penyidik lain tidak dapat melakukan tugas itu tanpa adanya perintah dari atasan langsung atau pimpinan. Demikian pula dalam hal pemeriksaan terhadap tersangka ataupun saksi, model yang digunakan sangat prosedural, misalnya pengisian berita acara pemeriksaan sesuai dengan formulir yang telah disiapkan sebagaimana yang telah ditetapkan.

Dalam hal-hal tertentu, misalnya ketika melakukan tindakan upaya paksa terhadap tersangka masih kental dengan cara-cara yang represif dengan harapan dapat memberikan ketertiban, namun melanggar nilai-nilai moral dan kemanusiaan. Ini menunjukkan kemunduran pemikiran hukum yang luar biasa, yaitu kembali pada tipologi hukum yang represif.

Dalam fakta-fakta sosial, ternyata sebagian besar pelaksanaan kewenangan kepolisian dalam tatanan hukum yang otonom, bahkan cenderung mundur kembali pada tatanan hukum yang represif yang mengandalkan otoritas organisasi yang telah memperoleh legitimasi dari lembaga politik.

\section{Lembaga Kejaksaan}

Institusi hukum ini sangat kuat dalam penggunaan pola prosedural organik dan sangat mengedepankan sistem hukum yang legallistik-positivistik.. Sebagai wakil negara yang ditunjuk untuk melaksanakan tugas utama penuntutan dan tugas tambahan lain sebagaimana yang telah ditentukan (misalnya sebagai penyidik dalam tindak pidana tertentu, tugas pengawasan dan pengendalian organisasi yang berkembang di masyarakat), sudah pasti lembaga ini mengedepankan pola otoritas atau kekuasaan yang kuat dan sangat terikat dengan aturan yang mengelilinginya.

Namun demikian, sebenarnya lembaga ini tidak konsekuen dalam melaksanakan kekuasaan, misalnya ketidakmampuan lembaga ini ketika harus menuntut pejabat negara yang bermasalah dengan hukum, Kejaksaan justru menempatkan diri sebagai pembela, bukan sebagai penuntut umum sebagaimana yang telah digariskan dalam asas-asas penegakan hukum.

Proses penegakan hukum yang mengandalkan prosedural terlihat ketika Kejaksaan melalui Jaksa Penuntut Umumnya melakukan koordinasi dalam penelitian berkas perkara yang diajukan oleh penyidik. Penelitian berkas perkara harus dalam prosedural yang ketat. Contohnya penentuan kelengkapan berkas perkara yang akan diajukan kepada pengadilan ditentukan dengan penetapan sudah lengkap (P21). Jika berkas perkara menurut Jaksa belum lengkap, maka berkas perkara tidak akan dinaikkan ke pengadilan dan kemungkinan perkara akan mengambang sangat mungkin terjadi. Dengan demikian ada nilai-nilai keadilan 
yang tidak terakumulasi dengan baik, misalnya hak-hak tersangka untuk segera diajukan perkaranya ke sidang pengadilan, hak korban untuk dilindungi dan sebagainya.

Model prosedural organik lain yang ditampilkan oleh Kejaksaan adalah ketika penentuan seseorang untuk menjadi Jaksa Penuntut Umum, orang itu harus lulus pengujian dan mengikuti pendidikan formal kejaksaan dengan syarat-syarat yang telah ditentukan. Seseorang tidak akan dapat diangkat menjadi Jaksa Penuntut Umum jika tidak melalui prosedural tersebut walaupun ia memiliki kemampuan dan pengalaman bekerja yang mungkin saja melebihi kemampuan Jaksa yang telah mengikuti pendidikan formal tersebut.

Pola ketaatan terhadap prosedural seperti itu dapat saja disalahgunakan, karena sifat kewajiban prosedural jika tidak diletakkan pada tataran yang seimbang akan menjadi kelemahan dan membuka peluang terjadinya $a$ buse of power dari pemegang otoritas lembaga tersebut.

\section{Lembaga Pengadilan}

Institusi pengadilan sebenarnya merupakan pranata hukum yang sangat menentukan dalam penegakan hukum, karena pada bagian inilah suatu perkara akan dinilai dan memperoleh putusan. Dalam institusi ini bekerja para pejabat yang diberikan otoritas kuat dalam menentukan status seseorang atau beberapa orang yang tersangkut dalam perkara tersebut.

Secara faktual, institusi pengadilan melalui para hakim nya juga masih sangat mengandalkan pola-pola prosedural organik. Seorang hakim atau majelis hakim tidak akan pernah memeriksa dan memutus perkara jika perkaranya tidak diajukan (sampai pada tataran ini cukup baik karena dapat menguntungkan hakim agar tidak hadapi kuantitas perkara yang menumpuk, dengan demikian dapat lebih konsentrasi pada kualitas pemeriksaan dan putusan, meskipun bernuansa prosedural baku).

Namun ketika perkara sudah dinaikkan oleh Jaksa Penuntut Umum dan dinyatakan lengkap, persoalannya baru muncul, karena mulai sejak pemeriksaan awal sampai pada penjatuhan vonis hukuman, semuanya bersifat prosedural legalistik yang positivistis. Hakim terikat dengan pola-pola yang telah ditentukan dalam aturan yang bersifat prosedural.

Pada pemeriksaan awal hakim diwajibkan untuk melakukan klarifikasi identitas terdakwa (memastikan apakah orang yang diajukan ke sidang pengadilan itu benar dan sesuai dengan yang dicantumkan dalam surat dakwaan Jaksa Penuntut Umum). Kemudian memastikan apakah terdakwa tersebut dalam keadaan sehat (jasmani / rohani) dan siap untuk diperiksa dan seterusnya. Dalam kaitan dengan ini bukan tidak mungkin terjadi kesalahan hakim, misalnya hakim tidak pernah mengecek kebenaran materiel identitas terdakwa, hal ini dapat dimanfaatkan sebagai kelemahan hakim oleh pihak-pihak tertentu yang ingin menyembunyikan pelaku yang sebenarnya. Atau dalam hal kesehatan terdakwa, prosedural ini seringkali dimanfaatkan oleh terdakwa melalui kuasa hukumnya untuk menyatakan tidak siap diperiksa dengan alasan sakit, sementara di luar sidang pengadilan mereka mempersiapkan langkah-langkah manipulatif untuk melemahkan pengadilan. Fakta ini dengan jelas kita lihat dalam kasus yang melibatkan pejabat negara sebagai terdakwa.

Pada pemeriksaan surat dakwaan maupun jawaban (replik-duplik), juga terlihat pola peradilan yang prosedural. Kita tidak pernah melihat atau 
menemukan jawaban yang diberikan secara langsung dari kuasa hukum terhadap dakwaan Jaksa Penuntut Umum ataupun sebaliknya. Jawaban baru akan diberikan dalam tenggang waktu yang ditetapkan oleh hakim yang memimpin perkara (ratarata 1 minggu). Prosedur ini sudah pasti memperlambat proses penyelesaian perkara dan menjadi penyebab penumpukan perkara.

Selanjutnya dalam pemeriksaan alat-alat bukti (pembuktian), juga menampilkan skenario yang telah ditentukan dalam prosedural legalistik positivistis. Misalnya ketika hakim hendak memeriksa seorang saksi, maka saksi itu harus disumpah, jika saksi menolak disumpah hakim akan menilai sebagai keterangan biasa saja (dilepaskan dari alat bukti saksi) dan jika bersesuaian dengan alat bukti lain atau saksi lain, maka hakim akan menjadikannya sebagai petunjuk.

Kemudian ketika akan menjatuhkan vonis, hakim terikat dengan prosedural "harus dilakukan dalam sidang terbuka", jika tidak maka putusan batal demi hukum. Bagaimana dengan perkara yang menyangkut pelaku anak di bawah umur, sudah tentu akan memberikan tekanan psikologis terhadap pelaku.

Berdasarkan fakta-fakta yang telah penulis gambarkan tersebut, jelas dalam penegakan hukum yang dilakukan oleh institusi peradilan pidana di Indonesia masih kental menggunakan tipologi hukum yang bersifat otonom dengan prosedural yang mengikat kuat sebagaimana yang telah ditentukan dalam peraturan yang legitimate.

\section{SIMPULAN}

Philippe Nonet dan Philip Selznick telah memberikan gambaran tentang hukum otonom sebagai tipologi hukum yang mengutamakan prosedur formal baku yang dilaksanakan oleh pranata-pranata hukum yang telah memperoleh legitimasi kuat dari negara dalam suatu pengaturan hukum yang positif.

Dengan demikian, dapat dikatakan hukum otonom telah memberikan legitimasi kuat kepada lembaga-lembaga penegakan hukum untuk menjalankan hukum berdasarkan aturan-aturan yang tersedia dengan format prosedural yang telah ditetapkan.

Karakteristik hukum otonom yang mengandalkan prosedural yang legalistik positivistis tersebut masih sangat kuat dilaksanakan dalam sistem peradilan pidana di Indonesia, baik oleh institusi Kepolisian, Kejaksaan maupun institusi peradilan (hakim). Demikian pula dengan institusi penegakan hukum lain walaupun tidak penulis gambarkan dalam tulisan ini, namun dapat kita rasakan dalam praktekpraktek hukum .

\section{DAFTAR PUSTAKA:}

Ali, Ahmad, Menguak Realitas Hukum, Kencana Prenada Media Group, Jakarta, 2008

Menguak Teori Hukum (Legal Theory) dan Teori Peradilan (Judicialprudence), Jakarta, Kencana Prenada Media Group, 2009.

Arinanto, Satya dan Triyanti, Ninuk, (Editor), Memahami Hukum: Dari Konstruksi Sampai Implementasi, Jakarta, Rajawali Pres, 2009.

Dimyati, Khudzaifah, Teorisasi Hukum (Studi Tentang Perkembangan Pemikiran Hukum di Indonesia 1945-1990), Surakarta, Muhammadiyah University Press, 2004. 
Nonet, Philippe and Selznick, Philip, Law and Society in Transition: Toward Responsive Law, Harper \& Row Publisher, New York, 1978.

Rahardjo, Satjipto, Hukum Progresif, Sebuah Sintesa Hukum Indonesia, Yogyakarta, Genta Publishing, 2009.

Sidharta, Bernard Arief, Refleksi Tentang Struktur Ilmu Hukum (Sebuah Penelitian Tentang Fundasi Kefilsafatan dan Sifat Keilmuah Ilmu Hukum Sebagai Landasan Pengembangan Ilmu Hukum Nasional Indonesia), Bandung, Mandar Maju, 2009. 